so satisfactorily in Dr. Matter's better judgment that a few days thereafter he came all the way from the South Side to my office and asked for and received from me, gratuitously, an abundant supply of the remedy with inhalers, and assured me he would give it a good trial in several cases he had and report to me the results. If he used it all it must have been with success, or he would naturally have cited its failure as the real grounds of attack upon it in the Journal.

It was not until after the mother, son and daughter of the Eppstein family had written me a letter thanking me for the service I had rendered in bringing to the aid of their physicians in the case the remedy which apparently saved their father's life. This letter of gratitude from the wife, son and daughter of Mr. Eppstein was published in the Tribune and afterward came to the notice of Dr. Matter, and it seems suddenly changed his good opinion of the merits of the remedy.

After saying that chlorin is totally absent he says: "I have myself verified the presence of a slight amount of hydrochloric acid and menthol in the air inhaled from it." So his chemical test is made by smelling the air inhaled from it. It is true that there is about one per cent. of menthol in it, put there to destroy the disagreeable odor of the chlorin. Let me assure you, Mr. Editor, that it does contain an abundance of chlorin, with a corrective.

He again refers to the alleged report of Dr. Gehrman of the City Health Department in order to make a point against the Bracelin remedy. In doing so, he even disregards the truth. As Dr. Gehrman has passively made contradictory statements, as a bacteriologist, in regard to this remedy, he will hardly thank his friend (?) for making him say: "It differs from all known antiseptics in one particular: The latter kill bacteria; but the bactericide does not." This would seem cruel, following what Dr. Gehrman aaid at a meeting held in the Health Commissioner's office on December 18th, in the presence of Drs. Cotton, Murdoch, Hawley, Bracelin, the Commissioner of Health and the writer, on being asked the result of his investigations by the Commissioner. He said :

"I am not prepared to say, so far as I have gone, that the vapor itself is a very strong germicide, but I will say that the liquid is very powerful and will kill Loeffler's bacilli in short order. I took five culture tubes containing serum which were all inoculated with the diphtheritic bacilli and subjected them to a treatment of Bracelin's liquid, each for one, two, five, ten and fifteen minutes respectively, and I found that the germs in all of the tubes were positively killed, except in the one that was exposed to the liquid for only one minute, and in that one I found life, but in the other four the bacilli were dead."

At the same meeting he further said: "I can see no possible danger in the inhalation of the vapor generated by the liquids constituting Bracelin's Bactericide.'

For the purpose of prejudicing the profession against the use of this remedy, he is trying to connect it with a remedy misnamed "Omnicura" and says: "Under the fostering genius of Mr. J. J. Russell it has come to blossom like an octopus at the side of Omnicura." Permit me to say, emphatically, that there is not now and never has been, directly or indirectly, any more relation or connection between Bracelin's Bactericide and the so-called "Omnicura remedy" than there is between the Kleb's Loeffler bacillus and the Ferris Wheel; either in ownership, discovery, similarity of application or mode of introduction. Bracelin's remedy is the discovery of a way to use chlorin by Dr. Bracelin, a regular physician of twentyone years' practice and in good standing in the profession. $\mathrm{He}$ asks physicians to give this remedy an impartial trial and thereby help him to prove what he claims, after which he will publish the formula for making the corrective by which be removes from chlorin its suffocating and irritating qualities while still preserving its therapeutic power.

As the best evidence of which the case is susceptible I will, in the presence of any gentleman who is sufficiently interested to know the truth, take a bottle of chlorin solution and place a teaspoonful of it in the Bracelin Inhaler with the acid to liberate the chlorin and develop at once a gas which is impossible for any human being to inhale. I will then put in another teaspoonful of the nascent chlorin, thereby doubling the dose, and add to it a few drops of Dr. Bracelin's corrective which I will first put upon my tongue to prove its harmlessness and render it as capable and as pleasant of inhalation almost as the air we breathe. This kind of proof should satisfy the most skeptical.

In a sneering way he speaks of the enduring fame that will henceforth attend the physician who writes a letter to The Tribune glorifying the Bracelin cure and says his name will be handed down to future generations. Whether it will be so far reaching into the dim vista of coming generations I can not say, but I firmly believe in the perpetuity of the names of those who show an honest disposition to benefit the condition of their fellow-men.

Should any Chicago physician desire to test this preparation, clinically, I shall be pleased to furnish it to him gratuitously.

J. J. Russeld.

\section{What the Good Book Says about Doctors.}

San Diego, Cal., May 26, 1896.

To the Editor:-In these days of Christian science, substitution(?),faith healing, proprietary medicines, et id genus omne, it is refreshing to recall the language of our ancient friend Ecclesiasticus, quoted verbatim from the 38th chapter of his sensible treatise. (I know not why it was relegated to the apocrypha.) Hear him.

1. Honor a physician with the honor due unto him for the uses which ye may have of him; for the Lord hath created him.

2. For of the Most High cometh healing, and he shall receive honor of the King.

3. Theskill of the physician shall lift up his head : and in the sight of great men he shall be in admiration.

4. The Lord hath created medicines out of the earth: and he that is wise will not abhor them.

5. Was not the water made sweet with wood that the virtue thereof might be known?

6. And he hath given men skill, that he might be honored in his marvelous works.

7. With such doth he heal (men) and taketh away their pains.

11. Give a sweet savour and a memorial of fine flour and make a fat offering as not being.

12. Then give place to the physician, for the Lord hath created him; let him not go from thee, for thou hast need of him.

14. For they shall also pray unto the Lord, that he would prosper that which they give for ease and remedy to prolong $\begin{array}{ll}\text { life. Very sincerely yours, } & \text { C. M. FENN, M.D. }\end{array}$

\section{Sero-therapy-et id omne genus.}

San Francisco, Cak., May 23, 1896.

To the Editor:-The announcement in your issue of May 16 (quoted from La Semaine Médicale), of two cases of mania cured at Montpellier by injections of serum from a recovered maniac, suggests boundless expectations from sero-therapy and other new agents. It is presumptive that insanity is a germ disease, and that bacteriologists will soon differentiate its specific microörganism. At present we can only speculate whether homicidal and suicidal mania, kleptomania, pyromania, dementia, etc., are due to the same or separate microbes; but obviously one ought to choose cultures from cases resembling the particular type of insanity under treatment.

We may anticipate also the early discovery that the vices of 